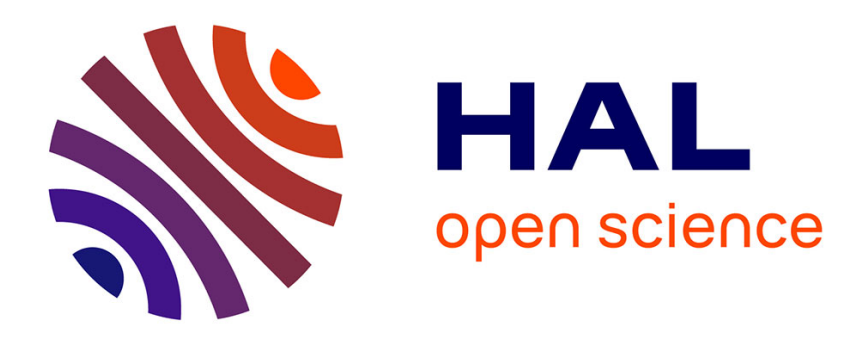

\title{
Behavioral changes mediated by hunger in honeybees infected with Nosema ceranae
}

\author{
Dhruba Naug, Ann Gibbs
}

\section{To cite this version:}

Dhruba Naug, Ann Gibbs. Behavioral changes mediated by hunger in honeybees infected with Nosema ceranae. Apidologie, 2009, 40 (6), 10.1051/apido/2009039 . hal-00892026

\section{HAL Id: hal-00892026 \\ https://hal.science/hal-00892026}

Submitted on 1 Jan 2009

HAL is a multi-disciplinary open access archive for the deposit and dissemination of scientific research documents, whether they are published or not. The documents may come from teaching and research institutions in France or abroad, or from public or private research centers.
L'archive ouverte pluridisciplinaire HAL, est destinée au dépôt et à la diffusion de documents scientifiques de niveau recherche, publiés ou non, émanant des établissements d'enseignement et de recherche français ou étrangers, des laboratoires publics ou privés. 


\title{
Behavioral changes mediated by hunger in honeybees infected with Nosema ceranae*
}

\author{
Dhruba NAUG, Ann GIBBS \\ Department of Biology, Colorado State University, Fort Collins, CO 80523, USA
}

Received 16 October 2008 - Revised 10 February 2009 - Accepted 28 February 2009

\begin{abstract}
The microsporidian Nosema is a common honeybee pathogen which enters the adult bee orally and multiplies in its gut, imposing a metabolic demand on its host. The newly discovered Nosema ceranae, given its relatively new association with the European honeybee, is likely to be particularly severe in this regard. We therefore hypothesized that $N$. ceranae exerts a significant effect on the feeding behavior of infected bees. Results from our experiments support this idea, revealing that infected bees are more responsive to sucrose and are less inclined to share this food with other bees, suggesting that they have a higher hunger level. We argue that increased hunger in the host is a general physiological effect of a number of pathogenic infections and due to its effect on host behavior could act as a mechanism by which the host and the pathogen can influence the transmission rates of an infection. Behavioral mechanisms, mediated by physiology could therefore be in the frontline of any arms race between a host and its pathogen.
\end{abstract}

host-pathogen interaction / behavioral alteration / hunger /appetite / Nosema ceranae / Apis mellifera

\section{INTRODUCTION}

Nosema is a microsporidian that commonly infects adult honeybees, the spores entering the host via the oral route, germinating in the midgut and subsequently invading the gut epithelium (Bailey, 1981). Studies with Nosema apis have shown that it imposes a high metabolic demand on the host (Roberts, 1968; Wang and Moeller, 1970a; Liu, 1984; Malone and Gatehouse, 1998) and causes behavioral alterations such as accelerated age polyethism (Hassanein, 1953; Wang and Moeller, 1970b). The newly reported Nosema species, N. ceranae, which has recently jumped hosts to the European honeybee (Higes et al., 2006), could be even more virulent in its effects given the observations that it causes a higher mortality in caged bees (Paxton et al., 2007) and that

Corresponding author: D. Naug, dhruba@lamar.colostate.edu

* Manuscript editor: Peter Rosenkranz infected colonies die if left untreated (Higes et al., 2008).

While $N$. ceranae has been implicated as a probable cause for the recent colony collapses characterized by the disappearance of adult bees from the colony (Higes et al., 2007, 2008; Martín-Hernández et al., 2007), surprisingly little research has focused on its effects on the behavior of infected bees. In a recent paper, we showed that foragers infected with $N$. ceranae incur an energetic stress, which increases their hunger and compromises their survival (Mayack and Naug, 2009). While we speculated that this could lead to infected foragers being more likely to forage under adverse conditions, a higher hunger level could also have a significant influence on the feeding behavior of bees within the colony. Any such changes in feeding at the individual and the social level could result in important changes in the transmission dynamics of an orally infecting pathogen such as Nosema. With this rationale, we assessed the appetite and hunger 
level of within-nest bees infected with $N$. ceranae and tested their willingness to share food with other bees.

\section{METHODS}

We collected within-nest adult bees from a colony of Apis mellifera L. that tested negative for Nosema ceranae infection using the multiplex PCR and electrophoresis method (MartinHernandez et al., 2007) and put them in cages. For controlled infection, each cage intended as a source for infected bees was inoculated by feeding it with $100 \mathrm{~mL}$ of $20 \%$ sucrose solution containing $N$. ceranae spores in a concentration $1 \times 10^{4}$ per $\mathrm{mL}$. while each cage meant for uninfected (control) bees received the same treatment without the spores. Two weeks after inoculation, we extracted bees from these cages to perform the following two experiments. A sample of 10 bees from each cage was also assayed for $N$. ceranae and bees from infected cages had a mean spore count of $65 \times 10^{3}$ while those from the uninfected cages had none.

\subsection{Gustatory responsiveness by PER}

For this experiment, we immobilized the bees on ice and mounted them into small plastic tubes, holding each bee with a piece of tape between its head and thorax. We fed each bee with $30 \%$ sucrose solution until she was satiated. We then tested the bees in groups of up to 30 at a time by touching their antennae with a droplet of sucrose, using a concentration series of $0.1,0.3,1,3,10$, and $30 \%$ sucrose by weight. Starting with the lowest concentration, the whole group was tested with a given concentration before moving to the next higher one in the series. Between two successive sucrose concentrations, we touched the bees on their antennae with water in order to reduce the effects of sensitization. We recorded a PER response when a bee fully extended her proboscis in response to a drop of sucrose being touched on each antenna. We performed this experiment on two sets of bees at different levels of satiety, (1) at satiation, and (2) 18 hours after satiation. Bees which did not respond to any concentration of sucrose during a trial were not included in the analysis.

\subsection{Food sharing in an arena}

We performed this experiment in an interaction arena that consisted of a square plastic box $(5 \times 5 \times$ $1.5 \mathrm{~cm})$ separated into two compartments by an insert (Farina and Núñez, 1991). After starving them for one hour after capture, we divided the bees into pairs of potential donors and receivers such that we had infected pairs and uninfected pairs. We placed a potential receiver in one of the compartments of the arena and fed a potential donor with $50 \mu \mathrm{L}$ of $20 \%$ sucrose solution containing $6 \mu$ polystyrene microparticles (Polysciences, PA) at a concentration of $1 \times 10^{7}$ per $\mathrm{mL}$. We then introduced the donor in the other compartment of the arena, removed the insert separating the donor and the receiver and allowed them to interact for 15 minutes, at the end of which we placed the arena with the bees in a box of dry ice to freeze-kill the bees instantly. We dissected the bees and enumerated the microparticles in the gut of each bee on a hemacytometer under a microscope to estimate the amount of food transfer that took place from the donor to the receiver.

\section{RESULTS}

\subsection{Gustatory responsiveness by PER}

This experiment was designed to determine if uninfected and infected bees differ in their appetite for sucrose by measuring their responsiveness to it at two different levels of satiation. We hypothesized that the higher level of energetic stress in infected bees should be reflected in their responsiveness to sucrose. We found a significantly higher proportion of PER responses by infected bees in comparison to uninfected bees, both when they are satiated (G test of independence: $\mathrm{G}=10.3, P=0.001$ ) and when they are starved for $18 \mathrm{hrs}(\mathrm{G}=7.8$, $P=0.005$, Fig. 1).

\subsection{Food sharing in an arena}

This experiment was designed to determine if there is a difference in the amount of food shared by infected and uninfected bees with their nestmates. We hypothesized that an infected bee due to its higher hunger level would be less willing to share food. Out of the total number of microparticles within the guts 


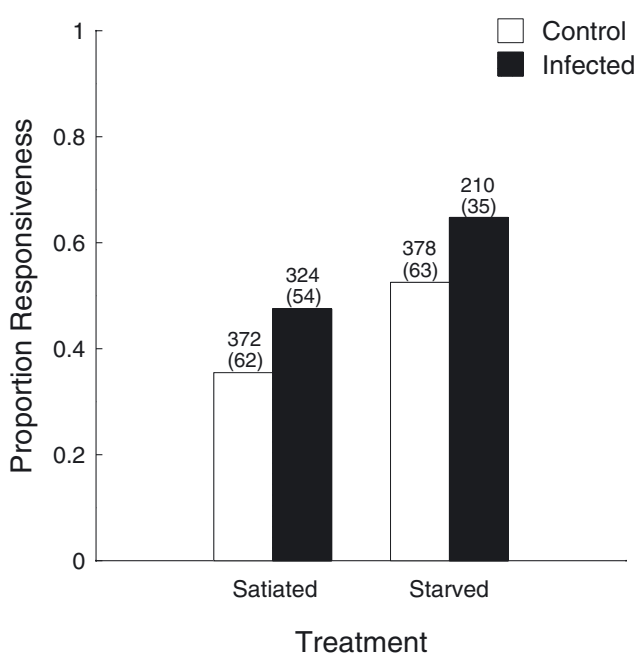

Figure 1. Responsiveness of uninfected and infected bees to sucrose when they are satiated and starved. Data are pooled across all concentrations offered and the numbers above each bar represent the number of antennal probes and in parentheses the number of bees tested in that group.

of a pair of donor and receiver, the proportion in the receiver indicates the extent of food transfer between the two. This proportion was significantly lower for the receivers in infected pairs than in uninfected pairs (One-way ANOVA: $\mathrm{F}_{1,144}=13.41, P<0.001$, Fig. 2 ).

\section{DISCUSSION}

The results support our initial premise that feeding behavior of within-nest bees is influenced as a result of infection with $N$. ceranae. Infected bees not only have a higher responsiveness to sucrose but also a lower inclination to share it with other bees. A higher consumption of sugar as a result of Nosema infection has been demonstrated earlier for foragers (Mayack and Naug, 2009) and at the level of the entire colony (Moffett and Lawson, 1975). Energetic stress and a corresponding increase in feeding in response to a pathogenic infection seem to be fairly general physiological effects, common to many insects (Rahman, 1970; Grimstad et al., 1980). It is therefore a mechanism that warrants more attention in

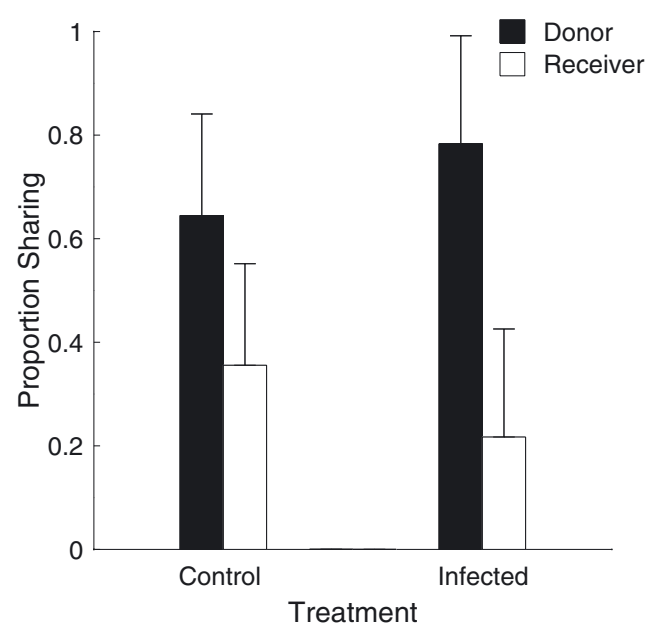

Figure 2. Extent of food sharing as given by the proportion of particles in the donors and receivers in uninfected $(\mathrm{N}=48)$ and infected $(\mathrm{N}=98)$ pairs. Data represent mean \pm s.d. and the statistical comparison is between the arcsine transformed proportions for receivers.

terms of its influence on the epidemiology of an infectious disease, especially in a social context where food exchange among individuals is an important process.

While Nosema is believed to be transmitted within the colony primarily via direct ingestion of spores, transmission via food transfer has been demonstrated in several cases including that to the queen (Hassanein, 1951; Bailey, 1972; Webster, 1993). We had earlier speculated that increased hunger in infected bees could increase trophallactic rates within the colony, thus increasing the potential for within-colony transmission of the pathogen. However, our results makes the dynamics seem somewhat more complex. While it is true that infected bees due to their hunger are more likely to beg for food, the same hunger also makes them averse to share any food that they have obtained. Therefore, further experiments would be necessary to fully determine the role of hunger on the transmission dynamics within the colony.

In a honeybee colony, the trophallactic potential of an individual is normally proportional to the volume of food in its crop and therefore infected individuals must act as sinks 
if they are to dampen a wave of infection that is propagating through the trophallactic network (Naug, 2008). Here we find supporting evidence for a possible mechanism by which individuals infected with Nosema can effectively turn themselves into sinks by reducing food sharing, thus decreasing the connectivity of the contact network within the colony. While increases in transmission potential mediated by alterations in feeding behavior has been suggested in many cases such as the mosquito vectored Dengue virus (Platt et al., 1997), cases where transmission is reduced by altered feeding behavior of the host are not as well known.

A dense, closely connected social group such as a honeybee colony is a particularly attractive host for a pathogen due to the excellent transmission opportunities and the homogenous microenvironment within it. However, the behaviorally mediated social organization within the colony also offers it a potential instrument to resist the rapid spread of a pathogen (Schmid-Hempel, 1998; Naug and Camazine, 2002; Naug and Smith, 2007). In such a setting, behavioral mechanisms, given their relative plasticity and economy are likely to be in the frontline of any arms race between the host and its parasite. There are many well known cases of behavioral alterations in the host as a response to infection, which sometime benefit the interests of the host and sometime those of the pathogen (Poulin, 1995). The findings of this study indicate that the alteration of a simple and ubiquitous physiological element - hunger - in a host individual by a pathogen could mediate behavioral changes that alter the dynamics of transmission and studying such effects are important for understanding the epidemiology of an infectious disease.

\section{ACKNOWLEDGEMENTS}

This study was made possible by a grant to DN and a REU support to AG from the National Science Foundation, USA. DN designed the experiment, AG collected the data, and DN wrote the paper. We thank Chris Mayack for identifying the Nosema species.
Modifications comportementales provoquées par la faim chez des abeilles infectées par Nosema ceranae.

Apis mellifera / interaction hôte-pathogène / modification comportementale / faim / appétit / syndrome d'effondrement des colonies / CCD

Zusammenfassung - Durch Hunger ausgelöste Verhaltensänderungen bei Honigbienen, die mit Nosema ceranae infiziert sind. Frühere Untersuchungen weisen darauf hin, dass pathogene Mikrosporidien der Gattung Nosema, die Bienen über den Verdauungstrakt infizieren, den Stoffwechsel des Wirtes belasten. Man kann daher erwarten, dass der neue Parasit $N$. ceranae, der kürzlich den Wirtswechsel zur europäischen Honigbiene Apis mellifera vollzogen hat, in dieser Hinsicht auch eine besondere Gefahr darstellt. Wir vermuteten, dass der zusätzliche metabolische Bedarf durch den Parasiten das Futterverhalten des Wirtes beeinflusst und dadurch Auswirkungen auf die Verbreitung des Erregers innerhalb des Bienenvolkes hat. Als erstes bestimmten wir den Grad des Hungers bei infizierten und nicht infizierten Bienen mit dem Rüsselreflex-Test (PER), indem wir die Reaktionen in beiden Bienengruppen gegenüber dem Angebot an unterschiedlichen Zuckerlösungen verglichen. Unsere Ergebnisse zeigen, dass die infizierten Bienen innerhalb des Bienenstockes stärker auf das Zuckerangebot reagieren, was auf einen stärkeren Hungerzustand hinweist. Als nächstes verglichen wir das Verhalten beim Futteraustausch zwischen den beiden Bienengruppen, indem wir eine Bienen mit einer Zuckerlösung fütterten, die eine bestimmte Anzahl von Mikropartikeln enthielt, und sie zusammen mit einer ausgehungerten Biene aus derselben Bienengruppe in eine Arena sperrten. Nach 15 Minuten zählten wir die Mikropartikel in beiden Bienen, wodurch wir den Umfang des Futteraustausches zwischen den beiden Bienen abschätzen konnten. Wir stellten fest, dass infizierte Bienen weniger Futter mit ihren jeweiligen Partnerinnen ausgetauscht hatten als nicht infizierte Bienen. Aus diesen Ergebnissen kann man ableiten, dass infizierte und damit hungrige Bienen zwar stärker um Futter betteln und damit potentiell die Verteilung des Erregers innerhalb des Bienenvolkes fördern; gleichzeitig kann aber die Abneigung dieser Bienen, das einmal erhaltene Futter mit anderen zu teilen, die Übertragung des Erregers reduzieren. Diese Ergebnisse lassen vermuten, dass sowohl der Parasit als auch der Wirt Vorteile durch diese Veränderung im sozialen Futteraustausch haben, der dadurch möglicherweise eine Frontlinie im evolutiven Wettstreit zwischen Wirt und Parasit darstellt.

Parasit-Wirt-Wechselwirkungen / Verhaltensänderungen / Hunger/ Appetit / Nosema ceranae / Apis mellifera 


\section{REFERENCES}

Bailey L. (1972) Nosema apis in drone honeybees, J. Apic. Res. 11, 171-174.

Bailey L. (1981) Honey bee pathology, Academic Press, London.

Farina W., Núñez J. (1991) Trophallaxis in the honeybee, Apis mellifera (L.) as related to the profitability of food sources, Anim. Behav. 42, 389-394.

Grimstad P., Ross Q., Craig G. (1980) Aedes triseriatus (Diptera: Culicidae) and La Cross virus. II. Modification of mosquito feeding behavior by virus infection, J. Med. Entomol. 17, 1-7.

Hassanein M. (1951) Studies on the effect of infection with Nosema apis on the physiology of the queen honey-bee, Q. J. Microsc. Sci. 92, 225-231.

Hassanein M. (1953) Infection with Nosema apis on the activities and longevity of the worker honeybee, Ann. Appl. Biol. 40, 418-423.

Higes M., García-Palencia P., Martín-Hernández R., Meana A. (2007) Experimental infection of Apis mellifera honeybees with Nosema ceranae (Microsporidia), J. Invertebr. Pathol. 94, 211-217.

Higes M., Martín R., Meana A. (2006) Nosema ceranae, a new microsporidian parasite in honeybees in Europe, J. Invertebr. Pathol. 92, 93-95.

Higes M., Martín-Hernández R., Botías C., Bailón E.G., González-Porto A.V., Barrios L., Nozal M.J., Bernal J.L., Jiménez J.J., Palencia P.G., Meana M. (2008) How natural infection by Nosema ceranae causes honeybee colony collapse, Environ. Microbiol. 10, 2659-2669.

Liu T.P. (1984) Ultrastructure of the midgut of the worker honey bee Apis mellifera heavily infected with Nosema apis, J. Invertebr. Pathol. 44, 282291.

Malone L., Gatehouse H. (1998) Effects of Nosema apis infection on honey bee (Apis mellifera) digestive proteolytic enzyme activity, J. Invertebr. Pathol. 71, 169-174.

Martín-Hernández R., Meana A., Prieto L., Salvador A., Garrido-Bailón E., Higes M. (2007) Outcome of colonization of Apis mellifera by Nosema ceranae, Appl. Environ. Microbiol. 73, 6331-6338.
Mayack C., Naug D. (2009) Energetic stress in the honeybee Apis mellifera from Nosema ceranae infection, J. Invertebr. Pathol. 100, 185-188.

Moffett J., Lawson F. (1975) Effect of Nosemainfection on $\mathrm{O}_{2}$ consumption by honey bees, J. Econ. Entomol. 68, 627-629.

Naug D. (2008) Structure of the social network and its influence on transmission dynamics in a honeybee colony, Behav. Ecol. Sociobiol. 62, 1719-1725.

Naug D., Camazine S. (2002) The role of colony organization on pathogen transmission in social insects, J. Theor. Biol. 215, 427-439.

Naug D., Smith B. (2007) Experimentally induced change in infectious period affects transmission dynamics in a social group, Proc. R. Soc. B 274, 61-65.

Paxton R., Klee J., Korpela S., Fries I. (2007) Nosema ceranae has infected Apis mellifera in Europe since at least 1998 and may be more virulent than Nosema apis, Apidologie 38, 558-565.

Platt K., Linthicum K., Myint K., Innis B., Lerdthusnee K., Vaughn D. (1997) Impact of Dengue virus infection on feeding behavior of Aedes aegypt, Am. J. Trop. Med. Hyg. 57, 119-125.

Poulin R. (1995) "Adaptive" changes in the behaviour of parasitized animals: a critical review, Int. J. Parasitol. 25, 1371-1383.

Rahman M. (1970) Effect of parasitism on food consumption of Pieris rapae larvae, J. Econ. Entomol. 63, 820-821.

Roberts M.D. (1968) Fatty acids in honey bees (Apis mellifera) infected with the protozoan Nosema apis, J. Invertebr. Pathol. 11, 234-236.

Schmid-Hempel P. (1998) Parasites in social insects, Princeton University Press, Princeton.

Wang D., Moeller F. (1970a) Comparison of the free amino acid composition in the hemolymph of healthy and Nosema-infected female honey bees, J. Invertebr. Pathol. 15, 202-206.

Wang D., Moeller F. (1970b) The division of labor and queen attendance behavior of Nosema-infected worker honeybees, J. Econ. Entomol. 63, 15391541.

Webster T. (1993) Nosema apis spore transmission among honey bees, Am. Bee J. 133, 869-870. 